\title{
CS-45 - Caracterización histórico-etnobiológica de la pesquería garínagu en arrecifes de bahía de Amatique del Caribe de Guatemala
}

\author{
Historic and etnobiologic characterization of Garinagu fisheries in \\ Amatique Bay reefs of the Caribbean of Guatemalan \\ Hugo Hidalgo Colindres*, Raúl Robles, Gabriel Vides
}

Instituto de Investigaciones del Caribe de Izabal (IICI) Centro Universitario de Izabal (Cunizab)

*Autor al que se dirige correspondencia: integramar@yahoo.es

\section{Resumen}

- sta investigación descriptiva sobre la pesquería de la etnia garífuna tuvo como objetivo caracterizarla y tratar de es- 1 tablecer relaciones existentes entre el conocimiento científico y etnobiológico de esta sociedad costera para conocer sus sitios de pesca (bajos-arrecifes), comercialización, visibilizar esta actividad históricamente olvidada, siendo la más amigable con el ambiente en la zona. El método utilizado fue reef cheek, además de viajes de reconocimiento, buceos para describir diversidad biológica, arrecifes, tipo de pesca y encuesta con herramienta de colecta de datos entrevista; principalmente a pescadores y mujeres comercializadoras de más de 40 años. Los resultados relevantes fueron: reconocer un fuerte conocimiento de pescadores sobre las características biofísicas de los remanentes de arrecife-coral, tortugas marinas, manatíes, comportamientos de peces y rol de la mujer en el sistema de comercialización. concluyéndose con un estudio retrospectivo de la pesquería garínagu, formación de Asociación de Pescadores Garífunas, incorporación a la Red de Pescadores del Caribe, identificación y afirmación de la existencia de los arrecifes en el Caribe e impulsar el artículo 44 en la ley de pesca 80-2002 que prohíbe la pesca con "tiro avión" en los 13 Bajos caracterizados. Fundamento para colocación de primer arrecife artificial y protección especial de bajo King Fish.

Palabras claves: Territorialidad, simbolismo, etnobiología, pesquería

\section{Abstract}

$\mathrm{T}$ his descriptive research about the Garifuna fisheries had like subjetc to do the characterization and to trate establish relations between the cientific and etnobiologic knoledge in this caribbean society to know fisheries sites (reefs-shoals), commercialization, place on spots lights the activity historically forgotten, being the more friendly with the enviroment in the zone. The methods used were the reef cheek, travels, diving to describe the biologic diversity, reefs, fisheries types and the poll and interview for datum colects, with focus in fishermen and commeercialization wimens with 40 old years. The more important results were: know a fishermen strong knoledge about biophysics characteristics at reef remnants, Sea Turtle, Sea Cow, fishes behavior at last the wimen rol in the system of commercialization. The conclusions were: One retrosopectiv report about the Garínagu fisheries, conformation of Fishermen Association, to incorporet in the fishermen Caribbean network, Identification and validation about the existence of caribbean reefs, boost the 44 articule in the fisheries law 80-2002 for ban the fishing with "tiro avión" in the 13 characterized shoals. At last this research was the fundament to place the first artifitial reef and the procces to give spetial protection to King Fish Shoal. 